NBER WORKING PAPER SERIES

\title{
THE GATT'S CONTRIBUTION TO \\ ECONOMIC RECOVERY IN \\ POST-WAR WESTERN EUROPE
}

Douglas A. Irwin

Working Paper No. 4944

\author{
NATIONAL BUREAU OF ECONOMIC RESEARCH \\ 1050 Massachusetts Avenue \\ Cambridge, MA 02138 \\ December 1994
}

This paper was prepared for the Association d'Economie Financiere/Deutsche Girozentrale Project on Domestic and International Sources of Post-WWII Recovery and Growth. Financial support was provided by the James S. Kemper Faculty Foundation Research Fund of the Graduate School of Business at the University of Chicago. I wish to thank the Division of International Finance at the Board of Governors of the Federal Reserve System for their hospitality during my stay as a visiting scholar when much of this paper was completed, as well as Barry Eichengreen and J. Michael Finger for helpful comments. This paper is part of NBER's research program in International Trade and Investment. Any opinions expressed are those of the author and not those of the National Bureau of Economic Research.

(C) 1994 by Douglas A. Irwin. All rights reserved. Short sections of text, not to exceed two paragraphs, may be quoted without explicit permission provided that full credit, including $($ ) notice, is given to the source. 


\title{
THE GATT'S CONTRIBUTION TO \\ ECONOMIC RECOVERY IN \\ POST-WAR WESTERN EUROPE
}

\begin{abstract}
This paper examines the role of trade liberalization under the auspices of the General Agreement on Tarrifs and Trade (GATT) in promoting economic recovery and growth in Europe in the decade after World War II. The formation of the GATT does not appear to have stimulated a particularly rapid liberalization of world trade in the decade after 1947 . It is therefore difficult to attribute much of a role to the GATT in the dramatic economic recovery during the immediate post-war period beyond that of an effective supporting actor. The principal contribution of the GATT during its first decade of operation rests more in securing binding agreements on early tariff reductions, thereby preventing countries from instituting higher tariffs as import quotas and foreign exchange controls were being phased out during the 1950s under the guidance of other international institutions.
\end{abstract}

Douglas A. Irwin

Graduate School of Business

University of Chicago

Chicago, IL 60637

and NBER 
The GATT's Contribution to Economic Recovery in Post-War Western Europe

Douglas A. Irwin

University of Chicago

\section{Introduction}

The contrast between the decade of economic instability in Western Europe after World War I and the economic recovery established in the decade following World War II is nowhere more evident than in the area of international trade relations. Economic reconstruction following World War I lacked any institutional mechanism to facilitate the reduction of trade barriers that had arisen during the war and had become entrenched thereafter. The political weakness of European countries in trade policy was evident when a proposal for "equality of trade conditions" in a draft League of Nations charter was rejected in favor of a weaker provision for "equitable treatment." The World Economic Conference in 1927 still found it necessary to call upon governments to remove wartime controls on trade, which included import quotas, licensing requirements, and foreign exchange controls. A decade after its formation, the League of Nations had yet to sponsor any negotiations on liberalizing world trade from high tariffs, and the onset of the depression vanquished any serious prospect of trade reform in Europe and elsewhere.

Yet during World War II, even in advance of official U.S. participation in the conflict, the United States and the United Kingdom already envisioned a post-war world trading system based on reducing all trade barriers and limiting discriminatory tariff preferences. Just two years after Germany's surrender, 23 countries established a General Agreement on Tariffs and Trade (GATT) that set rules to restrict national trade policies and even started to decrease tariffs in binding agreements. Just five years after the end of the war, all major Western European countries had participated in three separate 
negotiating rounds that had expanded GATT membership and further reduced import tariffs.

The GATT often has been hailed, almost by virtue of its very existence, as a key factor in promoting post-war recovery in Western Europe and in preventing a return to the disaster of the interwar period. By freeing Europe's regional and international trade from government restrictions, the GATT permitted economies to take advantage of specialization along lines of comparative advantage and thereby expand more rapidly and efficiently. While it is exceedingly difficult to quantify the impact of any institution on aggregate economic activity, prima facia evidence of the GATT's success arises from the divergence in the behavior of European trade after World War I - when no such institution was in place .. and after World War II - - when the GATT facilitated the reduction of trade barriers.

Figures 1 and 2 depict the path of a GNP-weighted average of export volume and real income for five major West European countries -- France, Germany, Italy, the Netherlands, and the United Kingdom - - after the two wars. By 1929, a dozen years after the war, the export volume of these countries had just barely surpassed its pre-war (1913) peak. After World War II, by contrast, exports surpassed their pre-war level in about five years, albeit the pre-war (1938) level was perhaps artificially low owing to protectionism and the depression. Still, exports expanded by a factor of eight in the decade after World War II compared with a four-fold increase after World War I. The picture for national income is similar. This favorable outcome cannot clinch the case for GATT's positive impact in promoting economic recovery after World War II, but the correlation between the dramatic increase in postwar trade and income and the establishment and activities of the GATT 
negotiations has weighed heavily in the minds of economists and policymakers.

This paper describes and assesses the contribution of the GATT in fostering economic recovery in Western Europe after World War II during on the decade from 1947 to 1956 . Three questions will be posed for consideration:

(1) What were the origins of the GATT and what did it aim to achieve?

(2) How successful was the GATT in liberalizing Europe's trade?

(3) Was the GATT responsible for the post-war export boom?

To anticipate the paper's main conclusions, the formation of the GATT does not appear to have stimulated a particularly rapid liberalization of world trade in the decade after 1947. It is therefore difficult to attribute much of a role to the GATT in the dramatic economic recovery during the immediate post-war period beyond that of an effective supporting actor. The principal contribution of the GATT during its first decade of operation rests more in securing binding agreements on early tariff reductions, thereby preventing countries from instituting higher tariffs as import quotas and foreign exchange controls were being phased out during the 1950s under the auspices of other international institutions. Yet despite the GATT's weaknesses on several fronts, the institution succeeded in establishing among major countries a fairly credible commitment to an open and stable environment for world trade that fostered the post-war rise in trade and income.

\section{The Origins and Purposes of the GATT}

Preparations for a new world trading order began during World War II and date from the Atlantic Charter (August 1941) and the Lend Lease (February 1942) agreements between the United States and the United Kingdom. In early discussions, both governments endorsed the principles of non-discrimination 
and free trade in post-war commercial policy. The British War Cabinet proposal on "Commercial Union" (drafted by James Meade) and the U.S. State Department document "Multilateral Convention on Commercial Policy" emerged in September-October 1943 and formed the basis for ongoing bilateral discussions until 1945. In December 1945, the State Department completed a draft multilateral accord on rules for international trade that was acceptable to both governments.

The architects of the post-war international economic order were principally concerned with establishing institutions and promoting policies that would avoid the repetition of the interwar experience. To this end, their first objective was to design a stable international monetary system that would allow for domestic policies to maintain full employment. The reduction of tariffs and elimination of quantitative restrictions on international trade was an important part of the broad objective, but was not viewed as urgent a priority as restoring monetary stability and achieving full employment. Consequently, while the Articles of Agreement of the International Monetary Fund (IMF) and the International Bank for Reconstruction and Development (IBRD) were formalized at the Bretton Woods conference in 1944 and took effect shortly thereafter, agreements and institutions on commercial policy materialized more slowly. That trade was placed on this second track was to have important consequences for the types of agreements and institutions that later emerged.

With the completion of a draft charter in 1945, the U.S. proposed opening international negotiations to finalize multilateral agreement on a charter for an International Trade Organization (ITO) that would take a place along side the IMF and IBRD. The ITO was to have wide scope over various 
aspects of international economic activity, with rules covering not just commercial policy but also employment, commodity agreements, restrictive business practices, and international investment. To hasten efforts at reducing tariff barriers, the U.S. also invited countries to participate in tariff negotiations in concert with the ITO talks. In February 1946, the Economic and Social Council of the United Nations resolved to convene an international conference on trade and employment to negotiate an ITo charter, and 18 countries attended a preparatory meeting in London during OctoberNovember 1946. In January-February 1947 at Lake Success, New York, negotiators drafted technical articles of the charter along with a preliminary general agreement on commercial policy, and a subsequent conference in Geneva prepared by August an ITO draft charter for submission to the UN conference. From November 1947 to March 1948, the UN Conference on Trade and Employment in Havana (composed of 56 countries) finalized and ratified the ITO charter. This approval came nearly four years after the Bretton Woods conference, over two years after the initial U.S. proposal for an ITO, and almost half a year after the first post-war negotiations on reducing tariffs (as will be discussed shortly).

The lack of urgency with which the ITO was created portended its demise as an institution. The Havana Charter languished for an additional three years as the agreement encountered domestic controversy in the United States during efforts to obtain formal approval. Business interests that had supported bilateral tariff negotiations in the 1930 s under the Reciprocal Trade Agreements Act of 1934 balked at supporting an internationa1 organization with wide-ranging regulatory authority over trade, investment, and business practices. The Executive Committee of the U.S. Council of the 
International Chamber of Commerce, as quoted in Diebold (1952a, pp. 20-21), denounced the draft ITO charter as a "dangerous document because it accepts practically all of the policies of economic nationalism; because it jeopardizes the free enterprise system by giving priority to a centralized national governmental planning of foreign trade; because it leaves a wide scope to discrimination, accepts the principles of economic insulation, and in effect commits all members of the ITO to state planning for full employment." Other pressing international concerns also prevented the Truman administration from viewing the ITO as a major priority and marshalling business support for the agreement; the United States was preoccupied with the Marshall Plan in 1948, with the North Atlantic Treaty Organization in 1949, and with the Korean War in 1950. In the face of continued opposition to the ITO, the Truman administration announced in December 1950 that the ITO would not be submitted for Congressional approval, effectively killing the agreement .

Fortunately, the collapse of the ITO did not extinguish the only means for liberalizing world trade policies. Also at the Geneva meeting in 1947, on a parallel track with the ITO negotiations, 23 nations agreed to enact revised versions of the commercial policy articles in the existing ITo draft charter - called the General Agreement on Tariffs and Trade - - and agreed to reduce tariffs amongst themselves. The agreement and the tariff reductions were finalized on October 30,1947 and came into force for most countries on January 1, 1948 - and did not require Congressional approval in the case of the United States. The GATT was viewed as an intermediate measure to implement the commercial policy clauses of the ITO and accelerate the reduction of tariffs on world trade while the ITO was being finalized. The 
GATT was never designed to exist as an institution itself, but only to serve as a temporary agreement until it could be absorbed into the ITO structure. The GATT immediately became the forum for early trade policy discussions, however, and in the wake of the ITO's failure became the sole body for overseeing international commercial policies.

The Geneva negotiations in 1947 that produced the GATT were undertaken by 23 participating countries, listed on table 1 , who became Contracting Parties. The purpose of the GATT, as stated in its preamble, was to contribute to rising standards of living and full employment by "entering into reciprocal and mutually advantageous arrangements directed to the substantial reduction of tariffs and other barriers to trade and to the elimination of discriminatory treatment in international commerce." Part I of the General Agreement contained two articles, the first mandating unconditional mostfavored-nation (MFN) treatment for all Contracting Parties and the second consisting of annexed schedules of all tariff reductions that arose during negotiations. Part II of the Agreement included the main rules on commercial policy but was applied "provisionally," meaning the Contracting Parties were obligated to implement them "to the fullest extent not inconsistent" with existing national legislation. Article XI contained a general prohibition on quantitative restrictions, although Article XII made an exception in the case of balance of payments safeguards. Article XIX described conditions under which a GATT obligation could be nullified or withdrawn with compensation for trading partners. Many of the other articles dealt with mundane issues such as customs valuation, marks of origin, and other technical matters. Part III of the Agreement contained articles on the functioning of the GATT. 


\section{What Did the GATT Accomplish?}

In light of the protectionist legacy of the 1930 s and the deeply entrenched state regulation of economic activity bequeathed by World War II, the GATT's agenda of trade liberalization and constraints on national discretion in trade policy was quite ambitious. The rules set down for the conduct of commercial policy were stringent, particularly unconditional MFN treatment for GATT members and the general prohibition of quantitative restrictions. There was sufficient latitude within the Agreement, however, to accommodate state behavior at variance with a strict interpretation of GATT rules. Colonial tariff preferences in effect in 1947 were not affected by the MFN requirement, quotas for balance of payments purposes were permitted, and import restrictions on agricultural and fisheries products were sanctioned. Gaining fuller adherence to all GATT rules by members was not immediately achieved and could only come with time -. indeed, it has yet to be attained even today.

But the most pressing objective of the GATT was to oversee the reduction of import tariffs and it was here that the GATT could make an important contribution to European recovery. These reductions took place over a series of negotiating rounds, three of which were held in the crucial, early post-war period.

First Round: Geneva, Switzerland, April - October 1947.

The Geneva negotiations in advance of the ITO's formation were motivated in part by the expiry of U.S. presidential negotiating authority in June 1948 . In 1945, Congress renewed the Reciprocal Trade Agreements Act of 1934 for three additional years and permitted the president to reduce U.S. tariffs up 
to 50 percent in reciprocal agreements. The pending expiration of this negotiating authority put pressure on international negotiators to conclude a preliminary agreement with the United States on reducing tariffs.

Consequently, 23 participating countries that accounted for roughly 80 percent of world trade successfully agreed to cut and bind tariffs in negotiations held from April to October 1947, with the tariff reductions designed to enter into effect in January 1948 for most countries.

The first several GATT rounds consisted of bilateral tariff negotiations a product-by-product basis under the principle of "reciprocal mutual advantage" and the principal-supplier rule. In preparation for the negotiations, countries would exchange lists of "requests" for tariff modifications on various products. Each country would consider a request for such a tariff "concession" on a given product only from the "principal supplier" of that product in exchange for a reduction in the principal supplier's tariff on another item of interest to the country. Under the "reciprocal mutual advantage" principle, no country would be forced to make any unilateral concessions. If a bilateral agreement was reached, the tariff reduction would then be "generalized," i.e., applied in an MFN fashion to all other GATT participants. Other countries would thus benefit from the tariff reduction, but it was up to the major supplier to a particular market to ensure that a given tariff in that market would be reduced. Thus, the GATT harnessed export interests in the negotiations to create the impetus for lower tariffs.

In the first Geneva round in 1947, according to the GATT (1949, p. 11), the 23 countries made not less than 123 agreements covering 45,000 tariff items that related to approximately one-half of world trade. The tariff 
reductions were certainly not across-the-board or applied to import-sensitive sectors such as agriculture, but concentrated on sectors that lacked the political strength to absolve them from consideration. Unfortunately, there is no convenient data on the precise depth of the tariff cuts of the Contracting Parties. The United States, however, calculated that the average cut in its tariff from existing levels amounted to 35 percent, as discussed in Finger (1979). As it is generally acknowledged that the United States made the deepest tariff cuts, this is probably the upper bound for the overall tariff reductions of European countries. The scaling down of the U.S. tariff was important for Western Europe because greater access to the U.S. market enabled these countries to earn scarce dollar reserves, which could then be used to purchase U.S. capital goods and other imports. To place an order of magnitude of the value of these tariff concessions would be a difficult exercise, but the United States deserves credit for taking the first and largest step on the road to lower tariffs and for providing the leadership that led to the GATT.

The Contracting Parties agreed that the tariff reductions negotiated at Geneva should remain in place for at least three years, until January 1, 1951. Thus the GATT provided some protection or safeguard against the nullification or impairment of these tariff "concessions" made in Geneva. This binding applied only to tariff concessions made in the Geneva negotiations, however, and other tariffs could be adjusted freely.

Second Round: Annecy, France, April 1949 - October 1949.

The primary purpose of the Annecy negotiations was to allow the accession of 11 other countries - listed on table 1 - - to the GATT as 
Contracting Parties. The original 23 members did not exchange tariff concessions with each other, but did negotiate with the 11 new members of the GATT and these tariff changes were generalized. This boosted the geographic scope of GATT membership and provided for a marginal reduction in tariff levels.

Third Round: Torquay. England, September 1950 - April 1951.

The third GATT round saw the original Contracting Parties again exchanging tariff concessions among themselves along with several new members acceding to the GATT, most importantly the Federal Republic of Germany. But the additional tariff reductions emerging from these negotiations were modest and the round was not considered a success. The official communique, cited in Diebold (1952b, p. 229), announced that the agreements were not "of such scope and magnitude as to represent a sufficient contribution to the reduction of existing disparities in the level of European tariffs." And the GATT (1952, p. 9) later stated that "the results of Torquay were not as broad or as extensive as some had hoped," with only 144 agreements reached out of an expected 400. Adding to the impression of failure was the announcement during the negotiations by President Truman that the ITO would not be sent to the Congress, thereby effectively killing the prospective institution.

The Torquay round ran into two problems that accounted for much of this failure: a dispute between the United States and the United Kingdom, and the growing disparity of tariff levels within Europe. The continuing dollar shortage in Europe prompted the United Kingdom to request unilateral tariff cuts by the United States, which the United States rejected on grounds of the reciprocal mutual benefit criteria. For its part the United States sought 
elimination or substantial reduction in tariff preferences within the British Commonwealth. After failures to find common ground, the United Kingdom agreed to reduce the preference margin only slightly so both sides could claim success in the negotiations, but neither side compromised significantly and there were no bilateral tariff cuts on U.S.-U.K. trade. The failure of both countries to agree on tariff concessions meant that others would not benefit indirectly from their generalization. According to Kock (1969, p. 71), "this attitude unfavorably affected countries that would have reaped indirect benefits from such tariff cuts and made them cautious about granting concessions in their own negotiations."

Also during the Torquay negotiations, the Benelux and Scandinavian countries argued that a new negotiating approach on tariffs was needed because the bargaining power of the low-tariff countries was limited and the GATT was not proving effective in reducing the tariffs of the high-tariff countries. The GATT charter stated that "the binding against increase of low duties or of duty-free treatment shall, in principle, be recognized as a concession equivalent in value to the substantial reduction of high duties or the elimination of tariff preferences." But adherence to this statement was not enforceable in practice because of the reciprocal mutual advantage provision. In September 1951, several countries proposed to drop the bilateral, product-by-product method of GATT in favor of a broader approach to liberalization. The "GATT Plan" -. put to the Contracting Parties in 1953 with the support of Belgium, Denmark, France, West Germany, and the Netherlands - - called for a 30 percent weighted-average reduction in tariffs to be phased in over three years. Tariffs were divided into product categories - raw materials, food, semi-processed goods, and industrial goods 
- and tariff rates were capped at mandated ceilings. The plan elicited little enthusiasm from the United States and the United Kingdom, which had both become resistant to further liberalization. The GATT plan as a multilateral approach lay dormant through the 1950s, although it became the method to eliminate tariffs within the European Economic Community and it was applied with great success in the Kennedy round of the 1960 s.

One positive result from Torquay was that the binding nature of all tariff reductions from the Geneva and Annecy rounds were renewed and extended until 1954 (and later extended again until the end of the 1950s). Before the rebinding of tariffs there was a brief window in which concessions could be moderated or withdrawn, but there were only a few minor instances of countries invoking this provision.

Widespread pessimism and frustration with the GATT process marked the end of the Torquay round. After a fruitful negotiating round in 1947 and a membership expansion in 1949, the GATT's momentum had suddenly stalled very early in the post-war recovery. After the difficulties at Torquay, more than five years elapsed before the next GATT conference, and that one (in Geneva in 1956) produced similarly meager results. GATT membership also stagnated: in January 1952, the GATT had 34 Contracting Parties that accounted for over 80 percent of world trade, but from 1952 to 1957, GATT membership increased by only one country on net, with the withdrawal of Liberia being balanced by the accession of Japan and Uruguay. The momentum toward lower tariffs was lost; further progress on reduced trade barriers had stalled.

Intransigence on both sides of the Atlantic accounted for the faltering of the GATT. One the one hand, "an important factor [behind the passivity during this period] was the growing protectionism in the United States, . . 
.there was a feeling that the United States had given away concessions without any real corresponding benefit, as the European countries were slow in eliminating their discrimination against dollar goods," writes Koch (1969, pp. 82, 84). On the European side, the United Kingdom refused to dismantle colonial preferences, and the low-tariff countries were frustrated by their inability to bargain effectively with high-tariff countries.

Thus, by 1951 the GATT was at a crossroads. The multilateral effort to reduce tariffs progressively was locked in a stalemate that continued through much of the 1950s. It is doubtful that an ITO, with its multifaceted agenda, could have expedited this process; indeed, things may have proceeded more slowly under an ITO owing to the greater complexity of issues it was designed to address. The pause in GATT activity reflected the transatlantic wrangle over the future course of trade negotiations, and a shift toward regional concerns where common objectives and interests were more readily apparent. Consequently, the GATT remained largely inactive in the 1950s while a European program of trade liberalization proceeded under the auspices of the Organization for European Economic Cooperation and the European Economic Community. Not until Dillon and Kennedy Rounds in 1961-62 and 1964-67 did the GATT return as the forum for a significant attempt at world trade liberalization. Thus, if the GATT had an impact on the immediate post-war economic recovery in Europe, it would come as a result of its accomplishments in the late 1940s.

So what were the major GATT achievements and shortcomings?

\section{a) Tariff Reductions}

The major achievement of the GATT was the extensive tariff reductions in 
the first negotiating round in Geneva. Unfortunately, as already noted, the extent of these tariff reductions is extremely difficult to quantify. The GATT itself refused to calculate the actual reductions for fear that they could be used by import-sensitive business interests to slow the liberalization process. Table 2 presents the sole official GATT calculation of tariff levels in major Western European countries for the year 1952, along with estimates from earlier years. The GATT figures did not include a calculation of tariff levels in 1947, just before the Geneva cuts went into effect, but a comparison with pre-war tariff levels suggest that tariffs were much lower in the United States and in Scandinavia by 1952 but remained higher in the United Kingdom, France, and Germany.

What the United States actually conceded in the GATT negotiating rounds is overstated by this calculation, however, because a significant amount of trade liberalization took place from 1934 - 1947 under the Reciprocal Trade Agreements Act. According to Lavergne (1983, pp. 32-33), these agreements cut tariffs by 44.0 percent on over 60 percent of U.S. trade (by value), amounting to a 33.2 percent reduction in duties overall and leaving duties at 66.8 percent of their level in 1930. The first GATT round in Geneva reduced duties 35.0 percent on just over 50 percent of all dutiable imports, making the overall tariff reduction 21.1 percent and leaving the U.S. tariff at 52.7 percent of its 1930 level. The Annecy and Torquay rounds cut tariffs on less than 12 percent of trade and barely made a mark on U.S. duties overall. While questions remain about the extent of the tariff cuts among European countries, there is also considerable uncertainty about the effects of the tariff cuts on trade. Because quantitative restraints and foreign exchange restrictions continued to be in place, it is not clear that the 
tariff reductions translated into more open market access in Europe. The U.S. market was demonstrably more open because it never resorted to quotas on manufactured goods, but European imports from the United States were hampered by dollar restrictions. Even within the European market trade was hampered by exchange controls and other restrictions.

For this reason, the tariff cuts from the Geneva and subsequent negotiations may have had a limited effect. One early study of the impact of GATT concessions by Lawrence Krause (1959, p. 55) found that "such tariff reductions as those given by the U.S. at Torquay do not lead to a significant increase in the volume of imports." However, the initial ineffectiveness of the tariff reductions - - particularly for European countries - - may have diminished over time as other forms of liberalization took place over the 1950s. As the GATT (1952, p. 8, emphasis added) itself recognized, "the cumulative effect of the three post-war tariff conferences will permit an expanding volume of trade at more moderate levels of customs duties, particularly when quantitative restrictions on imports are removed."

Indeed, the Geneva tariff cuts may have been larger than otherwise politically possible because they were viewed as initially neutralized by quantitative and foreign exchange restrictions. As Curzon (1965, p. 70) explains, "countries believing that quantitative restrictions would be a permanent feature of the post-war world gave sham but very substantial reductions on their tariff rates in exchange for real reductions from the only country not apply quotas on manufactured goods, i.e., the United States." "As quotas and discriminatory use of import licensing fade, ultimately vanish, the concessions exchanged at Geneva . . will acquire real substance," argued the Economist (23 April 1949, p. 757). In this respect, the initial tariff 
concessions may have been larger than countries had anticipated, and with time - - toward the end of the 1950s - their impact on trade may have become apparent. One could speculate that the GATT cut tariffs so significantly that it hindered efforts to eliminate quantitative and foreign exchange restrictions, but this contention lacks evidence.

\section{b) Tariff Bindings}

Each Contracting Party was bound to the terms of the GATT indefinitely, including any tariff concessions that became embodied in the annexes to Article II. While tariff concessions once given were considered fixed in perpetuity, countries retained the right to invoke Article XXVIII, which allowed countries to revoke tariff concessions after negotiating an agreement with the principal supplier or after accepting the withdrawal of equivalent concession from other countries. This article thus contained a mechanism by which the negotiated tariff cuts could unravel by mutual agreements.

To ensure the continuity and integrity of the Geneva cuts, and to provide for a measure of tariff stability that had been absent in the interwar period, the Contracting Parties at Geneva ruled out the right to invoke Article XXVIII for three years, i.e., until 1951, At the Torquay negotiations, this period of "firm validity" was extended through 1954, and was later extended again through 1957. Each time the period of "firm validity" was extended, a short window was offered to countries to modify their tariffs as allowed in Article XXVIII, but only minor withdrawals and modifications were taken by very few countries. Although reluctant to march toward further trade liberalization, countries at least recognized the gains from preventing an erosion in the early GATT successes. Freezing right to 
recourse to Article XXVIII ensured that the initial tariff cuts under the GATT would be preserved throughout the 1950 s even if no further progress was made in lowering tariffs and even as import quotas were being phased out. This may have been one of the GATT's major contributions to promoting economic recovery in Western Europe -. ruling out for an extended period reliance on tariffs to replace other trade barriers that were falling.

\section{c) Non-Discrimination}

Article I of the GATT makes unconditional most-favored-nation treatment a cornerstone of the Agreement. The major exception was for preferential tariff policies in effect in 1947, which included the United Kingdom (the Commonwealth), the United States (Cuba and the Philippines), France and the Benelux countries (their colonies), although the Contracting Parties agreed not to increase or establish new preferences. Only the British Commonwealth preference persisted as a major issue and in the first Geneva GATT negotiations the United States and the United Kingdom wrangled over the preferences. The U.K. adamantly refused to bend to U.S. opposition to these preferences, but a compromise in which preference margins were reduced defused the issue temporarily. The U.S. failure to achieve its long-held goal of eliminating the Commonwealth tariff preferences was never achieved.

Indeed, it soon became clear that a host of discriminatory policies in Europe would exist outside the GATT purview, as Finger (1993) has described. The Organization for European Economic Cooperation (OEEC), for example, began an effort to stimulate intra-European trade by eliminating license, quota, and exchange restrictions as they affected each other. Although this technically violated the GATT's MFN provision, the U.S. not merely acquiesced but 
encouraged this program as part of its policy to strengthen Europe. Koch (1969, p. 116) notes that "the OEEC policy was tacitly accepted without any waiver being asked for" and the, subsequently, the GATT has not posed as a barrier to discriminatory policies of this sort.

\section{d) Quantitative Restrictions}

For the achievements on the tariff front to be fully realized they needed to be matched by advances on the removal of quantitative restrictions (QRs). Article XI contains a general commitment of GATT members not to use QRs on trade. Article XIV, however, provides an exception in the case of the "post-war transition period" and Article XII permits the limited use of QRs in the context of short-term balance of payments problems. Their use for this reason came principally under the domain of the IMF and this justification remained viable into the 1950s. QRs were not even the subject of negotiation during the first three GATT rounds, and indeed did not come under GATT negotiations until the Dillon Round of 1961-62.

In 1950 , with the stalled Torquay round in process, the major Western European countries in the Organization for European Economic Co-operation (OEEC) agreed to a Code of Liberalization that set a timetable for the gradual elimination of QRs on intra-European trade. Discrimination continued against hard-currency countries such as the United States, but the OEEC achieved considerable success in freeing Europe's trade from QRs. The OEEC countries originally agreed to remove all quota restrictions on 50 percent of their imports in 1949, and the formal Code established targets of 60 percent in 1950 and 75 percent in 1951. Although some backsliding occurred in Germany in 1951 and in the United Kingdom and France in 1952, owing to balance of payments 
difficulties and an economic downturn, respectively, table 3 shows that this reversal proved temporary.

The OEEC program of progressively eliminating intra-European trade barriers, described in more detail by Boyer and Sallé (1955), provided a distinct boost to European trade. Figure 3 illustrates the volume of OEEC exports to other OEEC countries and to other countries. Intra-European trade grew in step with Europe's worldwide trade in 1947-49, but with the relaxation of quota restrictions in 1949-50, intra-European export volume jumped significantly above overall export volume. When further headway was made against QRs from 1953, the intra-European trade again grew more rapidly than overall trade. The OEEC's great success paved the way for the creation of a Common Market later in the decade.

Thus, significant progress on a key aspect of liberalizing trade came not from the GATT but from other European institutions. According to Kock (1969, p. 144), "The fact cannot be denied that OEEC contributed to a substantial relaxation of controls on intra-European trade in a period when the members of the OEEC felt that there was little prospect of getting results in the GATT." Yet the GATT was not entirely moot on the QR question. As she also points out (ibid.), "the [GATT] system of consultations led to constant pressure on member countries to motivate and defend their restrictive measures. . . Even if convertibility and economic expansion had been a contributory factor in the process of dismantling quantitative restrictions on industrial goods, there is no doubt that at a later stage GATT consultations were an important factor." 


\section{e) Assessment}

The impression is often given that the GATT, since its formation, has made consistent and incremental progress on trade liberalization. A reexamination of its first decade illustrates that this progress came quickly in the late 1940s and then languished for some time. Indeed, the GATT experienced many shortcomings during its first decade -. tariff cutting was rather limited, preferences and other discriminatory practices were not eradicated, and imports quotas were not abolished and fell outside its jurisdiction. In retrospect, the initial achievements of the GATT appear somewhat modest in light of its success in the Kennedy Round in the 1960 s and thereafter. The GATT diminished tariffs at its founding conference in 1947 , but the climate for further substantial reductions was not evident thereafter. In terms of concrete actions, the best that can be said for the GATT after 1947 is that it established non-discrimination as the presumption for the conduct of trade relations and, perhaps more importantly, that it held the line on the temptation for countries to substitute higher tariffs for liberalized quotas under the OEEC program.

The principal, initial effects of GATT may lie in the important but nebulous areas of credibility and commitment. That is, individuals and firms may be more willing to engage in trade if they suspect that governments are committed to certain tariff rates - - a stable trading environment -- and the outlook promises further, if uneven, progress on trade liberalization. The GATT gained some measure of credibility by virtue of its early agreement to reduce tariffs and expand membership. In sharp contrast to the frequent government proclamations in favor of freer trade during the interwar period, proclamations that were left hanging with no concrete action whatsoever, 
negotiators within the GATT actually secured and implemented an agreement to reduce tariffs just two years after the end of World War II. The GATT Contracting Parties demonstrated some commitment to this outcome by not allowing tariff concessions to expire, thereby avoiding the need to renegotiate trade agreements frequently, which had created problems for the pre-World War I tariff treaties, described in Irwin (1993). The interwar period was marked by the absence of any credible move toward trade liberalization or any demonstration of commitment to that objective, although the effect of these features of the GATT regime on economic performance cannot be ascertained in a precise way.

IV. European Trade under the GATT: A Comparison with the Post-World War I Experience

Despite what appears to have been very limited initial achievements, especially in light of subsequent trade liberalization, the GATT did make a firm break with interwar commercial policies and set world trade policies on a new path. And the outcome of the post-World War II period, in terms of the recovery in economic activity and international trade, has never been viewed anything but a great success exactly because in the decade following the war Europe managed to avoid the interwar catastrophe. The fact that this happened under the GATT's stewardship means that the institution itself stands to credit. But a closer comparison of the behavior of European trade and income during these two periods may shed light on what the GATT (and the OEEC) helped to accomplish.

Figures 1 and 2 depict the evolution of export volume and real income (weighted by GNP) for a sample of six major Western European countries -- 
France, Germany, Italy, the Netherlands, and the United Kingdom - - using data from appendices $A$ and $F$ of Maddison (1991). Figure 1 presents exports in the twelve years after the armistice (1918 - 1929) and after Germany's surrender (1946 - 1957). Figure 2 shows real income over the same period. Both figures also indicate the relevant pre-war level of exports and income - 1913 before World War I and 1938 before World War II. In the dozen years after World War I, incomes doubled and exports nearly quadrupled. In the dozen years after World War II, incomes almost tripled and exports grew eight-fold. Clearly, the post-World War II expansion was significantly greater than that after World War I. While it took seven years (to 1924) for European incomes after 1918 to match their pre-war level, just four years after World war II (to 1949) incomes reached their 1938 level. Exports after World War I matched their pre-war peak in eleven years (to 1928), while after World War II it took just six years (to 1951) for exports to surpass their 1938 level.

Yet the tremendous increase in export volume after World War II may reflect nothing more than this more rapid increase in income - owing perhaps to favorable macroeconomic factors rather than the GATT - - and the underlying relationship between trade and income could have remained relatively similar during the two periods. But econometric evidence points to substantial differences in the relationship between trade and income in the two post-war periods. Concerns about spurious correlation because of common trends rule out any regression of the levels of export volume and real income variables alone, so consider the following error-correction model which includes the variables in both levels and differenced terms:

$$
\Delta \mathrm{x}_{\mathrm{t}}-\beta_{1} \Delta \mathrm{y}_{\mathrm{t}}+(\alpha-1)\left(\mathrm{x}_{\mathrm{t}-1}-\gamma_{1} \mathrm{y}_{\mathrm{t}-1}-\gamma_{0}\right)+\varepsilon_{\mathrm{t}} \text {, }
$$

where $x_{t}$ is the $\log$ of export volume and $y_{t}$ is the $\log$ of real income. This 
equation relates the change in exports to the change in income and a lagged deviation of the long-run association of the two variables. This reflects both the short- and long-run interaction of the variables: the differenced terms capture the short-run impact of a change in income on the change in export volume; the error-correction mechanism, expressed in levels, allows exports to return to their long-run value (because $\alpha-1<0$ ). The long-run relationship is based on $x_{t}=\nu_{0}+\nu_{1} y_{t}+\nu_{2} y_{t-1}+\alpha x_{t-1}+\xi_{t}$, a structure sufficient to ensure that $\xi_{t}$ is white noise, and errors from the long-run solution are defined as $z_{t}=x_{t}-\gamma_{1} y_{t}-\gamma_{0}$, where $\gamma_{1}-\left(\nu_{1}+\nu_{2}\right) /(1-\alpha)$, which is the long-run elasticity of trade with respect to income, and $\gamma_{0}=$ $\nu_{0} /(1-\alpha)$. Subtracting $x_{t-1}$ from this equation and noting that $z_{t}=(1-\alpha)$ $\mathrm{x}_{\mathrm{t}}-\left(\nu_{1}+\nu_{2}\right) \mathrm{y}_{\mathrm{t}}-\nu_{0}$ yields the error-correction model.

To ascertain the short-and long-run impact of an increase in income on the volume of exports, the model is estimated using oLs for the periods 1919 1929 and 1947 - 1957 with a sample of five major West European economies (France, Germany, Italy, the Netherlands, and the United Kingdom) using Maddison's (1991) data. The estimation yields the following results (standard errors in parenthesis):

$\underline{1919-1929}$

$$
\begin{aligned}
& \Delta x_{t}-1.94 \Delta y_{t}-0.66\left(x_{t-1}-1.53 y_{t-1}+1.52\right) \\
& \begin{array}{lll}
(0.73) & (0.30) & (0.34)
\end{array} \\
& \begin{array}{llll}
\mathrm{R}^{2}=0.88 & \mathrm{~F}=30.9 & \sigma=6.4 \% & \mathrm{DW}=3.02
\end{array}
\end{aligned}
$$

$\underline{1947-1957}$

$$
\begin{array}{ccc}
\Delta \mathrm{x}_{\mathrm{t}}-1.40 \Delta \mathrm{y}_{\mathrm{t}}-0.63\left(\mathrm{x}_{\mathrm{t}-1}-2.33 \mathrm{y}_{\mathrm{t}-1}+5.49\right\} \\
(0.66) & (0.10) & (0.29) \\
\mathrm{R}^{2}=0.90 \quad \mathrm{~F}=34.2 \quad & \sigma=5.2 \% & \mathrm{DW}=2.60
\end{array}
$$

Although they must be interpreted with caution because of the short sample period, the results nonetheless provide some useful insights into the behavior of trade and income over the two post-war periods. The short-run 
impact of a change in real income was associated with a much larger increase in trade after World War I than after World War II -- 1.94 percent as opposed to 1.40 percent. However, the long-run elasticity of trade with respect to income $\left(\gamma_{1}\right)$ was substantially greater in the post-World War II era (2.33) than in the interwar period (1.53). These long-run relationships are sufficiently distinct from one another to suggest a much greater responsiveness of trade to rising income after World War II than after World War I. Furthermore, the long-run elasticity is greater than the short-run elasticity after World War II, indicating the effect of income on trade grew with time instead of reverting to a mean.

Unfortunately, the econometric results are incompletely informative about the underlying source of the difference in trade and income relationship after the two wars. It could well be that the mere presence of the GATT -- in stabilizing tariffs and committing countries to the path of trade liberalization .. spurred a more rapid increase in trade than seen after World War I, but alternative hypotheses are also consistent with the evidence and cannot be dismissed. Other post-war institutions aiming at international monetary stability, for example, may have fostered an environment that was conducive to international exchange, or domestic economic policies that were absent after World War I may have triggered the greater trade response.

Another plausible explanation for the greater trade-responsiveness to income after World War II was that a catch-up or convergence process in trade to GNP ratios was taking place. In the Western economies that later comprised the Organization for Economic Cooperation and Development (OECD), according to Maddison (1989, p. 143), the ratio of merchandise exports to GDP at current prices stood at 21.2 percent in 1913. This ratio fell to 18.9 percent in 1929 
as a result of World War $I$, and had fallen further to 15.1 percent in 1950 as a result of the depression and war-time disruptions. Consequently, there was ample room for international trade to be restored to a higher share of economic activity as normal, peacetime patterns of trade returned. Indeed, through the 1950 s and 1960 s the ratio gradually moved back to over 20 percent, where it had been in 1913. In any case, the fact remains that trade grew faster after World War II than after World War I not simply because incomes grew faster, but because the underlying relationship between the two had changed. And the trade liberalization under the GATT and the OEEC provides one conceivable explanation for this outcome.

These equations, which suggest that growth in trade arose from increases in real income, raise the related question of whether real income can truly be viewed as the exogenous, driving variable. An obvious alternative hypothesis, suggested by Bhagwati (1988) for example, is that expanding international trade led to higher real income after World War II. These regressions cannot even begin to address such complex, dynamic relationships between trade and income, but Irwin (1992) reports Hausman tests on similar regressions with a larger sample of countries and a longer sample period which indicate that, for econometric purposes, income is not endogenous with respect to trade and that a channel runs more distinctly from income to trade than from trade to income. This should not be interpreted as saying that trade had no effects on economic growth, but that these effects are more subtle than can be identified in annual, aggregate time-series data.

Furthermore, in a stark macroeconomic accounting sense, real net exports were a secondary contributor to rising real income in the early post-war period. Table 4 shows that real net exports never accounted for much more 
than a percentage point of economic growth in the OEEC countries (essentially all of Western Europe) and that domestic demand was the primary source of expansion. Yet the notable exception to this pattern is in 1948, the year in which the GATT tariff cuts first took effect, when net exports amounted to 3.3 percentage points of the 7.5 percent increase in the GNP of the OEEC countries. This may have been just part of the economic recovery from 1946 and 1947, but if the GATT actually made a contribution to this figure then post-war economic growth could have been even more rapid had the movement toward lower tariffs not stalled after about 1950.

\section{The GATT's Contribution: A Tentative Assessment}

One is left with tremendous uncertainty about the precise role of the GATT in promoting economic recovery in Western Europe in the first decade after the war. Its role was almost surely secondary to sound domestic macroeconomic and microeconomic policies. After all, the GATT did not achieve much for an entire decade after 1947 tariff cuts and 1949 membership expansion. These initial tariff cuts did not fully take hold until other trade restrictions were eliminated over the course of the 1950s. And the trade liberalization of the 1950 s that was of substantial importance took place outside of the GATT. The OEEC program of rolling back quantitative restrictions on intra-European trade, the Treaty of Rome and the elimination of tariffs within the European Economic Community, the unilateral liberalization by several countries - most notably west Germany, which in 1956 and 1957 cut its tariff by 25 percent each year - all these efforts complemented the GATT's objectives but did not originate from the institution itself. 
But a rather modest contribution by the GATT is probably to be found in two subtle but highly useful influences. First, the GATT set standards for state behavior, which -- even if far from being met initially - - at least created a reference point about the direction trade policies should be headed. The architects of the post-war economic system agreed that trade policy should be conducted on an open and non-discriminatory basis; by giving this objective an institutional basis they possibly prevented a drift in economic policy away from the principles embodied in the GATT. Second, while tariff cutting may have had no immediate effect in the immediate post-war environment, as the myriad of quotas and other restrictions on trade were gradually dismantled through the 1950s, the GATT ensured that countries could not substitute higher tariffs for these measures as their economies became more open to world markets.

The GATT, in other words, held the line on tariffs and did not allow them to undermine reforms elsewhere. For an ad hoc institution that was never designed to exist on its own, for an institution with no independent power and no financial resources or lending capability to ensure compliance to its rules, this was a notable achievement. This achievement came from a remarkably small organization which was largely dedicated to a single purpose. By concentrating its effort almost exclusively on tariffs, the GATT did not spread its scarce resources or political capital too thinly or lose sight of its main objective. One can speculate that this structure may have enabled it to be more effective than the ITO, whose multifaceted agenda and potentially sprawling bureaucracy might have proved an impediment to real action. The role of Eric Wyndham White, the first director of the GATT, in ensuring the survival of the institution during the dark days of the 1950 s so that it could 
see another, better day, should also not be left unmentioned.

If one is looking for the proximate cause for the economic recovery in Western Europe during the decade or so after 1945, the GATT is probably not the first or even the second place to look. Taking the several decades of post-war economic growth into one's perspective, however, it is hard not to attribute some role to the GATT, conceding at the very least that it served as an effective supporting actor. By setting standards and holding the line on tariffs as other trade restrictions were lifted, the GATT was not geared or positioned toward providing a quick boost to GNP, but was more akin to a longterm investment with a long-term payoff. This payoff may not have been fully realized until the late 1950 s when European currency convertibility had been restored and tariffs as trade barriers again mattered most. Then the stage was set for a major advance against tariffs which came with the Kennedy Round negotiations of 1964-67, when the GATT fulfilled the promise the architects of the post-war economic order had envisioned. 
Table 1

Participants at GATT Negotiating Rounds

\section{Geneva, 1947}

Australia, Belgium, Brazil, Burma, Canada, Ceylon, Chile, China, Cuba, Czechoslovakia, France, India, Lebanon, Luxembourg, the Netherlands, New Zealand, Norway, Pakistan, South Africa, Southern Rhodesia, Syria, the United Kingdom, the United States

\section{Annecy, 1949}

$$
\text { Above, plus }
$$

Colombia, Denmark, Dominican Republic, Finland, Greece, Haiti, Italy, Liberia, Nicaragua, Sweden, Uruguay

\section{Torquay, $1950-51$}

$$
\text { Above, plus }
$$

Austria, Germany, Guatemala, Korea, Peru, Philippines, Turkey

Note: Not all participants became Contracting Parties to the GATT.

Source: Various GATT publications 
Table 2

Average Tariff Levels in Select Countries

(in percent)

\begin{tabular}{||l|c|c|c|c|c||}
\hline & 1913 & 1925 & 1927 & 1931 & 1952 \\
\hline Belgium & 6 & 7 & 11 & 17 & n.a. \\
\hline France & 14 & 9 & 23 & 38 & 19 \\
\hline Germany & 12 & 15 & 24 & 40 & 16 \\
\hline Italy & 17 & 16 & 27 & 48 & 24 \\
\hline Netherlands & 2 & 4 & n.a. & n.a. & n.a. \\
\hline $\begin{array}{l}\text { United } \\
\text { Kingdom }\end{array}$ & n.a. & 4 & n.a. & 17 & 17 \\
\hline \hline \begin{tabular}{l} 
United States \\
\hline
\end{tabular} & 32 & 26 & n.a. & n.a. & 16 \\
\hline
\end{tabular}

Note: Not all years are comparable. Calculations for 1913 and 1925 are from the League of Nations as reported in GATT (1953, p. 62), also the source for the 1952 GATT calculation. For 1927 and 1931 tariff data, see Leipmann (1938), p. 415, and Kitson and Solomou (1990), pp. 65-66, for the United Kingdom in 1932 . 
Table 3

Liberalization of Intra-OEEC Trade, 1950-55

(percent, by end of year)

\begin{tabular}{||l|c|c|c|c|c|c||}
\hline & 1950 & 1951 & 1952 & 1953 & 1954 & 1955 \\
\hline France & 66 & 76 & 0 & 18 & 65 & 78 \\
\hline Germany & 63 & 0 & 81 & 90 & 90 & 91 \\
\hline Italy & 76 & 77 & 100 & 100 & 100 & 99 \\
\hline Netherlands & 66 & 71 & 75 & 87 & 88 & 96 \\
\hline United Kingdom & 86 & 61 & 44 & 75 & 83 & 85 \\
\hline
\end{tabular}

Source: OEEC (1959). 
Table 4

Sources of Growth in OEEC's Real National Product, 1948 - 1955

(percentage point contribution to change in GNP)

\begin{tabular}{|c|c|c|c||}
\hline Year & $\begin{array}{c}\text { National } \\
\text { Expenditure }\end{array}$ & $\begin{array}{c}\text { Net } \\
\text { Exports }\end{array}$ & $\begin{array}{c}\text { Gross } \\
\text { Nationa1 } \\
\text { Product }\end{array}$ \\
\hline \hline 1948 & 4.2 & 3.3 & 7.5 \\
\hline 1949 & 6.1 & 1.2 & 7.3 \\
\hline 1950 & 6.1 & 1.1 & 7.2 \\
\hline 1951 & 6.2 & -0.7 & 5.5 \\
\hline 1952 & 1.9 & 1.0 & 2.9 \\
\hline 1953 & 5.2 & 0.3 & 5.5 \\
\hline 1954 & 4.9 & -0.2 & 4.7 \\
\hline 1955 & 6.0 & 0.0 & 6.0 \\
\hline
\end{tabular}

Source: Calculated from the OEEC (1957), p. 39. 
Figure 1

Export Volume after World Wars I \& II

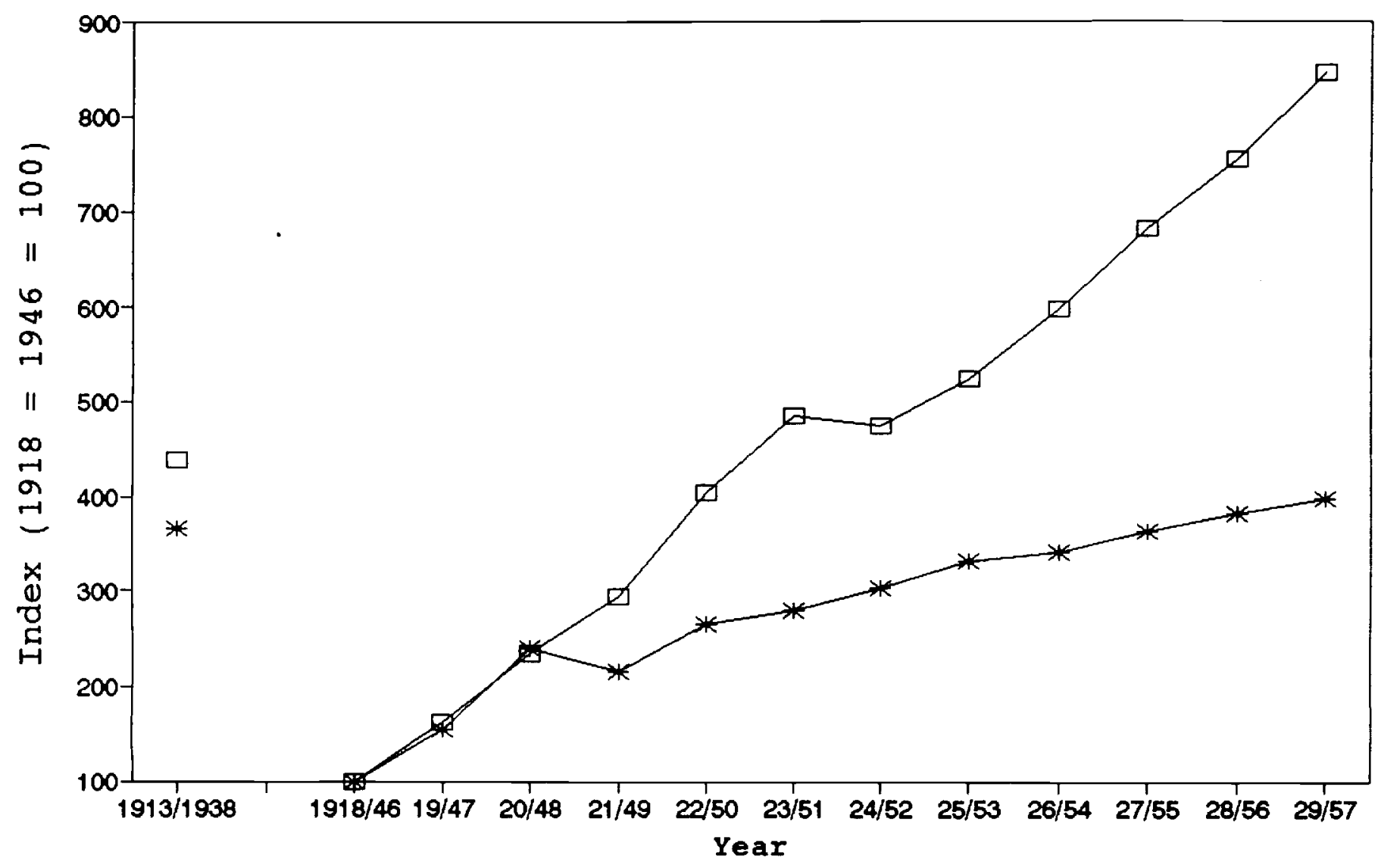

* After World War I $\square$ After World War II 
F1gure 2

Real Output after World Wars I \& II in Five west European Economies

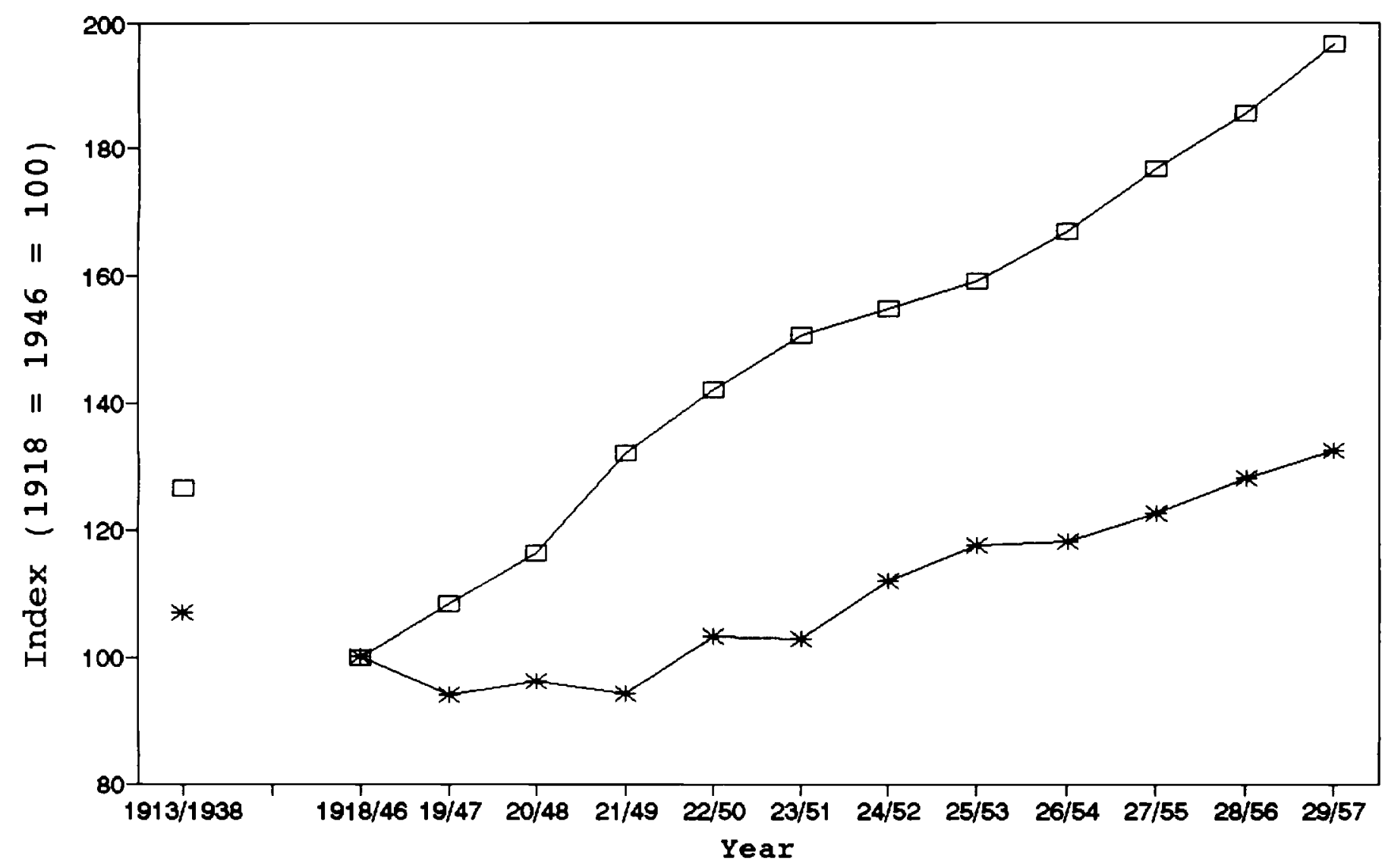

* After World War I $\square-$ After World War II 
Figure 3

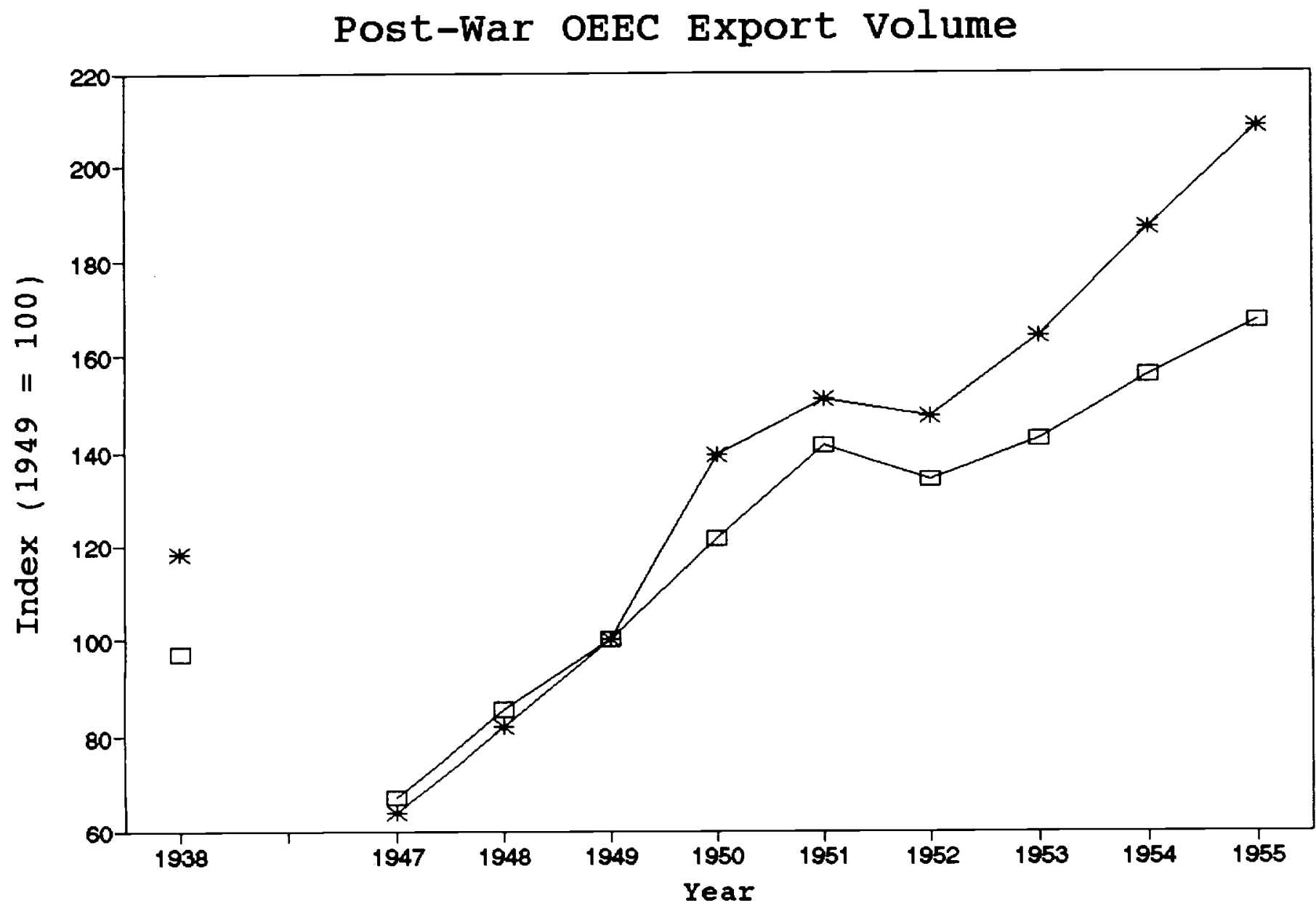

$\longrightarrow$ Intra-OEEC Exports $\square$ Extra-OEEC Exports

Source: OEEC (1956), p. 69 . 


\section{Bibliography}

Boyer, F., and J. P. Sallé, "The Liberalization of Intra-European Trade in the Framework of the OEEC," International Monetary Fund Staff Papers 4 (February 1955): $179-216$.

Bhagwati, Jagdish, Protectionism (Cambridge: MIT Press, 1988).

Curzon, Gerard, Multilateral Commercial Diplomacy: The General Agreement on Tariffs and Trade and its Impact on National Commercial Policies and

Techniques (London: Joseph, 1965).

Diebold, Jr., William, "The End of the ITO," Essays in International Finance

No. 16, International Finance Section, Princeton University, October 1952. (a)

Diebold, Jr., William, Trade and Payments in Western Europe: A Study in Economic Cooperation, 1947-1951 (New York: Harper for the Council on Foreign Relations, 1952). (b)

Finger, J. M., "Trade Liberalization: A Public Choice Perspective," in Challenges to a Liberal International Economic Order, eds. Ryan C. Amacher, Gottfried Haberler, and Thomas D. Willett (Washington: American Enterprise Institute, 1979).

Finger, J. M., "GATT's Influence on Regional Arrangements," in J. de Melo and A. Panagariya, New Dimensions in Regional Integration (New York, Cambridge University Press, 1993).

General Agreement on Tariffs and Trade, The Attack on Trade Barriers, A Progress Report on the Operation of the GATT, January 1948 - August 1949 (Geneva, August 1949).

General Agreement on Tariffs and Trade, Liberating World Trade, 2nd Report on the Operation of the GATT (Geneva, June 1950).

General Agreement on Tariffs and Trade, GATT in Action, 3nd Report on the Operation of the GATT (Geneva, January 1952).

General Agreement on Tariffs and Trade, International Trade, 1952 (Geneva, June 1953).

Irwin, Douglas A., "Long-Run Trends in World Trade and World Output," unpublished manuscript, University of Chicago, 1992.

Irwin, Douglas A., "Multilateral and Bilateral Trade Liberalization in the World Trading System: An Historical Perspective," in New Dimensions in Regional Integration, eds. J. de Melo and A. Panagariya (New York: Cambridge University Press, 1993).

Kitson, Michael, and Solomos Solomou, Protectionism and Economic Revival: The British Interwar Economy (Cambridge: Cambridge University Press, 1990). 
Koch, Karin, International-Trade Policy and the GATT, 1947-1967 (Stockholm: Almquist and Wikse11, 1969).

Krause, Lawrence B., "United States Imports and the Tariff," American Economic Review 49 (May 1959): 542-551.

Lavergne, Real P., The Political Economy of U.S. Tariffs: An Empirical

Analysis (New York: Academic Press, 1983).

Liepmann, Heinrich, Tariff Levels and the Economic Unity of Europe (New York: Macmillan, 1938).

Maddison, Angus, Dynamic Forces in Capitalist Development (New York: Oxford University Press, 1991).

Maddison, Angus, The World Economy in the 20th Century (Paris: OECD, 1989).

Organization for European Economic Co-operation, Statistical Bulletin, No. 4, July 1956 (Paris, 1956).

Organization for European Economic Co-operation, Statistics of National Product and Expenditure, No. 2, $1938 \& 1947-1955$ (Paris, 1957).

Organization for European Economic Co-operation, A Decade of Cooperation: Achievements and Prospects, 9 th Annual Report (Paris, April 1958). 